tukasz Iluk

Wyższa Szkoła Finansów i Prawa w Bielsku-Białej

lukasz@iluk.katowice.pl

\title{
WPEYW PODESŚCIA TRANSLACYJNEGO NA EFEKTYWNOŚĆ I POPRAWNOŚĆ PRZEKŁADU TEKSTU PRAWNEGO W RAMACH ĆWICZEŃ TRADUKTOLOGICZNYCH
}

DOl: http://dx.doi.org/10.12775/RP.2016.011

Zarys treści: Niniejszy artykuł dotyczy eksperymentu translacyjnego, którego celem było przekonanie studentów o niskiej skuteczności tłumaczenia za pomocą słowników i bez odpowiedniej wiedzy o sposobie utekstowienia materii prawnej. Polegał on na przełożeniu niemieckiego przepisu prawa na język polski w dwóch etapach: w części pierwszej studenci mogli korzystać ze słowników, w drugiej fazie eksperymentu ten sam tekst miał zostać przełożony za pomocą tekstu paralelnego. Miał on posłużyć jako wzór utekstowienia podobnych treści na poziomie terminologicznym, gramatycznym i stylistycznym. W drugiej części eksperymentu studenci mieli zostać przekonani do stosowania bardziej efektywnych strategii przekładu, w której ważną rolę odgrywa wiedza prawna, a zwłaszcza umiejętność ustalania przepisów regulujących podobną materię w wyjściowym i docelowym systemie prawnym. Okazało się, że zmieniając podejście translacyjne, można uzyskać znaczącą poprawę wszystkich parametrów przekładu, bez przeprowadzania dodatkowych ćwiczeń.

Słowa kluczowe: ekwiwalencja funkcjonalna, tłumaczenie w oparciu o teksty paralelne, tłumaczenie tekstów prawnych

\section{Wstęp}

Inspiracją do tego artykułu były wyniki eksperymentu translacyjnego przeprowadzonego wśród studentów pierwszego roku na specjalizacji tłumaczeniowej w zakresie języka prawniczego i ekonomicznego w Instytucie Filologii Germańskiej UŚ. Odbył się on w ramach przedmiotu Wstęp do prawoznawstwa niemieckiego. 
Generalnym celem eksperymentu było empiryczne przekonanie studentów o niskiej skuteczności tłumaczenia za pomocą słowników i bez odpowiedniej wiedzy o sposobie utekstowienia materii prawnej. Z reprezentatywnych badań Małgorzewicz (2012: 183 i n., 2013: 88) wynika bowiem, że nowicjusze lub niewystarczająco przygotowani tłumacze bezkrytycznie i nieumiejętnie korzystają ze źródeł leksykograficznych, a nawet są od nich uzależnieni. Natomiast Kielar (2007: 30, 2013: 113) zwraca uwagę na to, że tłumacz bez odpowiedniej wiedzy specjalistycznej naśladuje cechy powierzchniowe elementów tekstu wyjściowego, mechanicznie podstawiając terminy wyjęte z języka docelowego, kalkując struktury nazw lub konstrukcje składniowe. Stosując tego typu strategie, ryzykuje się tym, że przekład nie będzie wystarczająco komunikatywny, czym naruszy zasadę uzyskania tego samego efektu komunikacyjnego. Skutkują one również tym, że użyta w translacie terminologia łamie normy preskryptywne obowiązujące $\mathrm{w}$ danym systemie prawnym. Taki sposób przekładu zdaniem Kielar (2010: 144) stwarza niebezpieczeństwo zbaczania na bezdroża dosłowności, co zagraża nawet wytrawnym tłumaczom, nie wspominając o nowicjuszach. W drugiej części eksperymentu studenci mieli zostać przekonani do stosowania bardziej efektywnych strategii przekładu, w których ważną rolę odgrywa wiedza prawna, a zwłaszcza umiejętność ustalania przepisów regulujących podobną materię w wyjściowym i docelowym systemie prawnym. Okazało się, że zmieniając podejście translacyjne, można uzyskać znaczącą poprawę wszystkich parametrów przekładu, bez przeprowadzania dodatkowych ćwiczeń. By lepiej zrozumieć procedurę stosowania tej metody, niezbędne jest przedstawienie jej teoretycznych założeń i problematyki.

\section{Wybór ekwiwalentów terminologicznych}

Podstawowym elementem każdego tekstu specjalistycznego jest swoiste słownictwo, którego trzon stanowią terminy. Od słownictwa ogólnego odróżnia je to, że ich znaczenie jest na ogól ściśle zdefiniowane i dzięki temu tworzą mniej lub bardziej spójne systemy pojęciowe (Lukszyn, Zmarzer 2001: 21). Styl nominalny tekstów prawnych sprawia, że przekład tekstu specjalistycznego na inny język w dużej części może polegać, najogólniej rzecz ujmując, na zastępowaniu terminów z języka wyjściowego terminami języka docelowego. W przypadku translacji tekstów prawnych i prawniczych tłumacz zastępuje nazwy pojęć w systemie prawnym kraju języka wyjściowego nazwami pojęć systemu prawnego języka docelowego. Proces ten jest ściśle związany 
z problemami poszukiwania i wyboru stosownych ekwiwalentów i nie może przebiegać mechanicznie i bez pogłębionej refleksji (Iluk 2015: 634).

Zdaniem Boquect'a (1994, za: Pommer 2006: 35) faza poszukiwania ekwiwalentu terminologicznego w systemie prawa docelowego ma charakter czysto prawnoporównawczy. Polega ona na tym, że porównuje się instytucje wyjściowego systemu prawnego $\mathrm{z}$ instytucjami prawnymi systemu docelowego. Podobny pogląd w tej sprawie reprezentują de Groot (2002: 223-224), Pieńkos (2003: 106) i Zieliński (2005: 39) ${ }^{1}$. Ich zdaniem poszukiwanie odpowiednika terminologicznego musi opierać się na porównaniu systemów prawnych i stosownych siatek pojęć, co wiąże się z gruntowną wiedzą prawniczą, której tłumacze z reguły nie posiadają. Porównanie takie

powinno prowadzić do wskazania odpowiedniego terminu, pojęcia albo instytucji w języku docelowym, których funkcja będzie taka sama lub podobna, jak w tekście źródłowym. Chodzi tu o tzw. ekwiwalent funkcjonalny. (Pieńkos 2003: 110).

Problem poszukiwania odpowiedników terminologicznych w przekładzie prawnym i prawniczym dostrzega również Schmidt-König (2005: 120).

Die Schwierigkeit der juristischen Übersetzung und insbesondere der juristischen Äquivalenz besteht daher in der Suche eines Begriffs in der Zielrechtssprache, der im Vergleich zum Begriff aus dem Ausgangsrechtssystems in der Ausgangsrechtssprache zum einen eine äquivalente Definition besitzt und zudem äquivalent im Zielrechtssystem geregelt ist.

Zgodnie z zacytowaną myślą, poszukiwanie odpowiednika terminologicznego polega na znalezieniu w systemie prawa docelowego pojęcia, które jest zdefiniowane ekwiwalentnie do pojęcia w systemie wyjściowym. Na podstawie definicji można zatem ustalić zakresy pokrywania się pojęć i znaczeń w przyporządkowanym im nazwom. Zgodnie z poglądem Stolze (1999: 49) poszukiwane odpowiedniki terminologiczne muszą wykazywać przynajmniej jakieś wspólne minimum pojęciowe. Odmiennego zdania są autorzy Kodeksu tłumacza przysięłlego z komentarzem (Kierzkowska 2005: 92). Opowiadają się oni za tym, aby zakresy semantyczne potencjalnych ekwiwalentów terminologicznych pokrywały się w stopniu najwyższym. Pogląd ten precyzuje Kielar (2010: 142) w taki sposób, że ekwiwalencja terminów

${ }^{1}$ Zdaniem Zielińskiego (2005: 46) porównanie systemów prawnych jest warunkiem wstępnym i niezbędnym do wykonania dobrego przekładu. 
na poziomie konceptualnym ma wykazywać wspólność cech istotnych oraz większości cech drugorzędnych ich znaczeń. Natomiast Sandrini (1996: 140) uważa, że ekwiwalentne terminy mają mieć tożsame intensje, podczas gdy ich ekstensje nie muszą się pokrywać. De Groot (1990: 124) radzi, aby zakres znaczeniowy poszukiwanego ekwiwalentu w tekście docelowym nie był ani za szeroki, ani za wąski w stosunku do znaczenia pojęć w tekście wyjściowym. Wymienione tu postulaty mają charakter kryteriów, którymi ma kierować się tłumacz w wyborze ekwiwalentu terminologicznego, natomiast nic nie mówią o tym, w jaki sposób efektywnie go poszukiwać.

Ustalenie zakresu pokrywania się znaczeń, tj. istniejących podobieństw i różnic, między potencjalnymi parami terminologicznymi w języku prawa wymaga szczegółowej analizy pojęciowej (de Groot 1990: 124; Pieńkos 2003: 106; Schmidt-König 2005: 108). Zdaniem Kielar (2007: 30)

Tłumacz nie powinien [...] mechanicznie podstawiać terminów wyjętych z języka docelowego, oznaczających podobne instytucje prawne, ale musi badać stopień ich ekwiwalencji funkcjonalnej i/lub formalnej. Ma przy tym szukać podobieństw instytucjonalnych, ale zarazem nie utożsamiać ze sobą rzeczy niewystarczająco podobnych.

Faza ta jest tożsama z porównaniem systemów prawnych. Poszukując ekwiwalentnych terminów w docelowym języku prawnym, „tłumacz musi nieustannie uruchamiać swoją wiedzę o regulowanej prawem dziedzinie (czyli wiedzę «dziedzinową», "merytoryczną») oraz wiedzę prawną i prawniczą, aby negocjować znaczenia, uwzględniając zakres wspólnej wiedzy o świecie i odpowiedniej wiedzy prawnej i prawniczej przewidywanych odbiorców" (Kielar 2007: 29). Tak więc podstawowym warunkiem efektywnego poszukiwania ekwiwalentu na podstawie porównania systemów prawnych jest odpowiednia wiedza prawna.

Rozumienie tekstów prawnych stawia na pierwszym planie materię prawną, a nie wyrażenia językowe. $Z$ tego punktu widzenia znaczenie pojęcia prawnego należy interpretować $\mathrm{w}$ ramach kontekstu systemowego i z perspektywy jego celowości. Natomiast tłumacz bez odpowiedniej wiedzy prawniczej kurczowo trzyma się słownictwa, zwłaszcza jego budowy morfologicznej i motywów nazwotwórczych. Semantyzacja nazw prawnych na podstawie ich pozornie transparentnej struktury leksykalno-semantycznej wydaje się tłumaczowi oczywista, co motywuje go do kalkowania wzoru semantycznego języka wyjściowego. W przypadku terminologicznych różnic interlingwalnych strategia kalkowania skutkuje naruszeniem ekwiwalencji normatywnej 
(Berdychowska 1999: 267). Zdaniem Pieńkosa (2003: 111) skrupulatna transpozycja tekstu prawniczego za pomocą dosłownych odpowiedników często prowadzi do przekładu niezrozumiałego dla odbiorców.

\section{Strategia poszukiwania ekwiwalentów terminologicznych w tekstach prawnych}

W swoim modelu transkodowania tekstu dla celów translacyjnych proponuję wyróżnić następujące fazy:

1. Precyzyjne ustalenie ekwiwalentnych źródeł terminologicznych, tj. dziedziny prawa, a często nawet konkretnych przepisów w wyjściowym i docelowym systemie prawa, które regulują daną materię prawną. Wymóg ten gwarantuje zachowanie ekwiwalencji dystrybucyjnej terminów prawnych (Iluk 2015: 638).

2. Ustalenie na podstawie stosownych przepisów optymalnych odpowiedników funkcjonalnych $\mathrm{z}$ uwzględnieniem stopnia ich ekwiwalencji pojęciowej. Faza ta wymaga stosownej wiedzy specjalistycznej oraz dokonania odpowiedniej analizy konfrontatywnej. Według Sandriniego (1996: 158) w centrum takiego porównania znajduje się funkcja normy prawnej, która jest środkiem do rozwiązania konkretnego problemu prawnego. Na tym tle porównuje się terminy pod kątem ich funkcji regulacyjnej w ramach określonej normy prawnej.

3. W ostatniej fazie przekodowuje się ustalone znaczenia na język docelowy w taki sposób, aby były zrozumiałe i wywoływały ten sam efekt komunikacyjny. Do tego dochodzą takie aspekty jak poprawność gramatyczna, stylistyczna i in.

4. W przypadku luk pojęciowych należy zastosować odpowiednie strategie kompensacyjne (Matulewska 2005: 65).

\section{Opis eksperymentu translacyjnego}

Eksperyment translacyjny został przeprowadzony na 40-osobowej grupie studentów pierwszego roku filologii germańskiej UŚ, których stopień znajomości języka niemieckiego odpowiada generalnie poziomowi B2 wg ESOKJ (2001). Polegał on na przełożeniu niemieckiego tekstu na język polski w dwóch etapach: w części pierwszej studenci mogli korzystać ze słowników, $\mathrm{w}$ drugiej fazie eksperymentu ten sam tekst miał zostać przełożony za pomo- 
cą tekstu paralelnego ${ }^{2}$ - miał on posłużyć jako wzór utekstowienia podobnych treści na poziomie terminologicznym, gramatycznym i stylistycznym.

$\mathrm{Na}$ każdym etapie studenci otrzymali 15 minut na wykonanie zadania. Po dokonaniu pierwszej próby przekładu studenci mieli ocenić trudność tekstu w skali $1-5$, przy czym 1 oznaczała tekst bardzo trudny, a 5 - tekst bardzo łatwy. Ponadto mieli podać źródło pomocy i ocenić jego przydatność w procentach. Na zakończenie zadania mieli wymienić czynniki utrudniające wykonanie przekładu.

Po przeprowadzeniu badania kontrolnego zaprezentowano badanym metodę ekwiwalencji funkcjonalnej w ujęciu teoretycznym oraz praktycznym. Następnie przeprowadzono badanie właściwe.

Eksperyment miał uzmysłowić studentom:

- stopień przydatności słowników w poszukiwaniu ekwiwalentów w języku docelowym,

- problem identyfikacji terminów prawniczych, których słowoforma jest identyczna ze słownictwem wspólnoodmianowym,

- zalety korzystania z tekstów paralelnych jako źródła terminologii.

\subsection{Wybór tekstu do przekładu i jego ocena}

Do przekładu wybrano $₫ 99$ niemieckiego kodeksu cywilnego (BGB) o następującej treści:

\section{$\$ 99$ Früchte}

(1) Früchte einer Sache sind die Erzeugnisse der Sache und die sonstige Ausbeute, welche aus der Sache ihrer Bestimmung gemäß gewonnen wird.

(2) Früchte eines Rechts sind die Erträge, welche das Recht seiner Bestimmung gemäß gewährt, insbesondere bei einem Recht auf Gewinnung von Bodenbestandteilen die gewonnenen Bestandteile.

(3) Früchte sind auch die Erträge, welche eine Sache oder ein Recht vermöge eines Rechtsverhältnisses gewährt.

Wybór tego tekstu do eksperymentu translacyjnego nie był przypadkowy. Ze względu na ograniczone ramy czasowe musiał on być w miarę krótki, stanowić zamkniętą całość, nieskomplikowany pod względem gramatycz-

2 Teksty paralelne według Krzysztoforskiej-Weisswasser (1995: 18) to „teksty tego samego typu, na ten sam temat, które powstały w takiej samej sytuacji komunikacyjnej”. Więcej na temat tekstów paralelnych w Kubacki 2013. 
nym oraz zawierać w dużym stopniu słownictwo wspólnoodmianowe, tj. takie, którego można używać we wszystkich odmianach językowych. Wybrany tekst składa się z trzech, relatywnie krótkich zdań przydawkowych. Można było więc założyć, że długość zdań oraz ich transparentne relacje gramatyczne nie powinny być czynnikami w specjalny sposób utrudniającymi proces przekładu. Pod względem leksykalnym tekst wyjściowy zawiera w zdecydowanej większości rzeczowniki języka ogólnego: Recht, Frucht, Sache, Erzeugnis, Ertrag, Ausbeute, Bestimmung, Gewinnung, Bestandteil, Bodenbestanteil, a także czasowniki: sein, gewähren i gewinnen. Jedyną trudność stanowi wyraz vermöge, którego forma może być mylnie łączona $\mathrm{z}$ czasownikiem vermögen. W przypadku takiego skojarzenia poprawne zrozumienie frazy, w której ten wyraz został użyty, jest niemożliwe. Uważny tłumacz dostrzeże natomiast, że po vermöge kolejne słowo występuje $\mathrm{w}$ dopełniaczu, dlatego vermöge należy interpretować jako przyimek. Z dokonanych przekładów wynika, że jest on studentom germanistyki zupełnie nieznany, co spowodowało, że nie podjęto żadnej próby jego przekładu. W starszych wydaniach niemieckiej gramatyki Helbiga i Buschy (np. z 1984 roku) vermöge nie był ujęty w katalogu przyimków, natomiast w Gramatyce niemieckiej $z$ uwagami konfrontatywnymi Darskiego (2012: 303) jest on odnotowany z kwalifikatorem stylistycznym "przestarzały”, a w Langenscheidts Großwörterbuch, Deutsch als Fremdsprache (1993: 1055) opatrzony jest kwalifikatorem „książkowy” (geschrieben). Z tego względu interpretacja frazy z vermöge wymaga uważnej lektury słownika.

\section{Stopień trudności tekstu}

W ocenie prowadzącego eksperyment wybrany tekst do przekładu należy uznać za trudny. Na poziom jego trudności składają się następujące czynniki:

- Struktury zdaniowe są pozornie bardzo proste. Zdanie główne składa się z łącznika, a w zdaniu przydawkowym $\mathrm{w}$ funkcji orzeczenia występują czasowniki gewinnen lub gewähren. Przyglądając się jednak uważniej tym zdaniom, można zauważyć, że ich konstrukcja odpowiada strukturze definicji legalnych, za pomocą których niemiecki normodawca precyzuje termin Früchte. Ich cechą charakterystyczną jest to, że wyrażenie definiujące (tzw. definiens) wymienia cechy definiowanego pojęcia.

- Użyte w definiensie rzeczowniki Gewinnung, Ertrag, Ausbeute, Erzeugnisse mają charakter synonimiczny i tworzą wspólne pole leksykalne. Użycie w krótkim tekście synonimicznych określeń może implikować 
aktualizowanie niuansów semantycznych, trudnych do odczytania przez mało doświadczonego translatora.

- Użyte w definiensie rzeczowniki są polisemiczne także w języku ogólnym, co również może utrudnić selekcję właściwego znaczenia ${ }^{3}$.

\section{Ocena tekstu przez studentów}

Większość studentów oceniła trudność tekstu na 2, uznając go za trudny. $\mathrm{Z}$ wyrażanych opinii wynika, że źródła swoich trudności dostrzegali w:

- wieloznaczności wyrażeń,

- braku znajomości pojęć,

- trudnym słownictwie,

- brakach leksykalnych, w tym w słownictwie specjalistycznym,

- trudności w znajdowaniu ekwiwalentów w słownikach,

- dziwnej składni zdań,

- braku znajomości tematu.

Studenci potwierdzili w swoich wypowiedziach, że po przeczytaniu tekst wydawał się zrozumiały, ale trudny do przełożenia. Na wrażenie zrozumiałości mógł wpłynąć fakt, że występujące w niemieckim tekście słowoformy były im znane. Niemniej - jak napisali - „ciężko było im ułożyć go po polsku w logiczną całość". Powodem tego była z jednej strony trudność w selekcji znaczeń wyrazów aktualizowanych w tekście, z drugiej „dziwna składnia zdań”. To ostatnie wrażenie może wynikać z faktu, że studenci nie zidentyfikowali zdań do przekładu jako definicji legalnych, w definiensie których uściśla się znaczenie terminów prawnych.

\subsection{Wykorzystane pomoce leksykograficzne}

Udział wiedzy własnej użytej w przekładzie studenci ocenili średnio na poziomie $30-40 \%$. W pozostałej części studenci deklarowali korzystanie z dwujęzycznych słowników niespecjalistycznych oraz słowników online. Badani szacowali, że udział pomocy leksykograficznych w wykonaniu zadania kształtował się na poziomie 60-70\%. Jednakże stwierdzili, że „czasem słowniki bardziej wprowadzają w błąd, niż pomagają”. Zatem sprawdźmy, czy ich opinie są uzasadnione.

${ }^{3}$ Według Dudena (online) np. wyraz Ertrag ma następujące znaczenia: bestimmte Menge (in der Landwirtschaft) erzeugter Produkte; finanzieller Nutzen, Gewinn, den etwas einträgt. 
Propozycje polskich odpowiedników niemieckich terminów Früchte, Früchte einer Sache i Früchte eines Rechts w niemiecko-polskim słowniku Kilian (1996: 240, 2009: 284) nie spełniają normy preskryptywnej z dwóch powodów. Po pierwsze, w słowniku stawia się znak równości pomiędzy owocami, płodami i pożytkami, sugerując, że są to synonimy terminu Früchte. Po drugie, podane polskie odpowiedniki pożytki z prawa i pożytki $z$ rzeczy są formalnie niepoprawne, bo nie spełniają normy preskryptywnej art. 53 i 54 Kc. Zgodnie z podanymi przepisami prawidłową formą jest fraza z przydawką dopełniaczową - podobnie jak w języku niemieckim - pożytki prawa i po$\dot{z} y t k i$ rzeczy. Zadziwiające jest to, że w słowniku polsko-niemieckim (Kilian 2000: 263) podaje się ich prawidłowe formy: pożytki prawa i pożytki rzeczy. Podobnie utożsamia się terminy Früchte i Nutzungen w wersji polsko-niemieckiej tego słownika. Taka sugestia bez dodatkowego wyjaśnienia różnicy między tymi terminami może wprowadzać w błąd użytkownika słownika. Niemieckie odpowiedniki polskich terminów w słowniku Kilian wykazują skrajną ekwiwalencję formalną, odzwierciedlającą formę i semantykę składników nazw polskich. Podane odpowiedniki niemieckie nie spełniają normy preskryptywnej z $\$ 99$ BGB, np. zivilrechtliche Nutzungen einer Sache i natürliche Nutzungen einer Sache. Co więcej, takich terminów w BGB w ogóle brak. Zastosowana tutaj ekwiwalencja formalna świadczy o niestosowaniu ekwiwalencji funkcjonalnej, która w przypadku tekstów prawnych ma swoje merytoryczne uzasadnienie, m.in. takie, że analizowane tu terminy mają precyzyjne definicje legalne, które determinują formę gramatyczną, liczbę składników i sposób ich zespolenia ${ }^{4}$. Wskazany problem wynika stąd, że autorzy słowników nie identyfikują grup wyrazowych jako terminów prawnych, często zdefiniowanych legalnie i do których należy stosować odpowiednie normy preskryptywne.

Autorce słownika można również zarzucić brak konsekwencji, bo w słowniku niemiecko-polskim podaje źródło terminu, czego nie zrobiła w słowniku polsko-niemieckim. Taka informacja jest ważna, wszak umożliwia tłumaczowi weryfikację adekwatności podanych odpowiedników pod względem preskryptywnym. Na uwagę zasługuje również fakt, że inne słowniki specjalistyczne w ogóle nie zawierają hasła Früchte $e^{5}$ albo są pod względem merytorycznym i formalnym błędne $e^{6}$. $Z$ powyższego wynika, że opinia studentów jest $\mathrm{w}$ tym wypadku w pełni uzasadniona.

\footnotetext{
4 Zob. analizę terminów w rozdz. 3.4.

5 Np. Kozieja-Dachterska 2006.

6 Np. Kienzler 2007 oraz Pawęska 2008.
} 


\subsection{Ocena przekładu tekstu w pierwszej fazie badania}

\section{Efektywność przekładu}

Z analizy wszystkich prac wynika, że za pomocą słowników studenci nie byli $\mathrm{w}$ stanie wykonać przekładu $\mathrm{w}$ zaplanowanym czasie. W ciągu przewidzianych 15 minut na wykonanie zadania 90\% studentów nie ukończyło przekładu. Ponad połowa przełożyła mniej niż 50\% tekstu. Świadczy to o tym, że znaczną część czasu zajmowała im mało skuteczna lektura słowników.

\section{Jakość przekładu}

Z przeprowadzonej analizy prac pod kątem jakości przekładu należy stwierdzić, że studenci wykonali zadanie źle lub bardzo źle. W każdej pracy użyto niewłaściwych ekwiwalentów. Najczęściej pojawiającymi się błędami były takie, które wynikały ze stosowania odpowiedników słownikowych, które nie uwzględniały kontekstu prawnego.

Tabela 1. Zestawienie terminów prawidłowych i użytych nieprawidłowo

\begin{tabular}{|l|l|l|}
\hline Słowoformy/frazy & $\begin{array}{l}\text { Przykłady przekładu termi- } \\
\text { nów w translatach studenc- } \\
\text { kich }\end{array}$ & $\begin{array}{l}\text { Przekład prawidłowy, zgod- } \\
\text { ny z ekwiwalencją funkcjo- } \\
\text { nalną Kc }\end{array}$ \\
\hline Früchte & owoce & pożytki \\
\hline Erzeugnisse & wyroby, produkty & płody \\
\hline sonstige Ausbeute & $\begin{array}{l}\text { pozostała eksploatacja, inne } \\
\text { korzyści }\end{array}$ & inne zyski \\
\hline Erträge & wyniki & dochody \\
\hline der Bestimmung gemäß & w odpowiednim znaczeniu & stosownie do przeznaczenia \\
\hline gewähren & gwarantować, przyznawać & przynosić* \\
\hline Bodenbestandteile & części nieruchomości & części składowe gruntu \\
\hline
\end{tabular}

$\mathrm{W}$ analizowanych pracach powszechnie zdarzały się przypadki bezrefleksyjnego przekładu dosłownego, wynikające z niezakwalifikowania wy-

* Studenci nie dostrzegli, że czasownik gewähren w zdaniu przydawkowym aktualizuje inne (specyficzne) znaczenie niż w standardowych kontekstach. Duden (online) parafrazuje je w następujący sposób: jemandem durch sein Vorhandensein etwas zuteilwerden lassen, ilustrując je następującymi przykładami z języka ogólnego: Die Musik gewährte ihm Trost. Diese Einrichtung gewährt große Sicherheit, Ihnen manche Vorteile. Zgodnie z polskim kontekstem prawnym i przy zachowaniu ekwiwalencji funkcjonalnej czasownik gewähren powinien zostać przetłumaczony jako przynosić. 
stępujących tu nazw i ich składników jako terminów prawnych, np. Früchte einer Sache tłumaczono jako owoce pewnej sprawy. Niektóre terminy, np. die gewonnenen Bestandteile nie zostały przetłumaczone w żadnej pracy ze względu na nieumiejętność selekcji aktualizowanego znaczenia jednego ze składników w danym kontekście (np. tu czasownika gewinnen). Inne przełożono merytorycznie błędnie, np. Bodenbestandteile jako części nieruchomości. Ponadto stosowano nie tylko niepoprawne ekwiwalenty, ale także niewłaściwą składnię i stylistykę. W rezultacie dokonany przekład był w całości niezrozumiały, tak jak to ilustruje poniższy przykład.

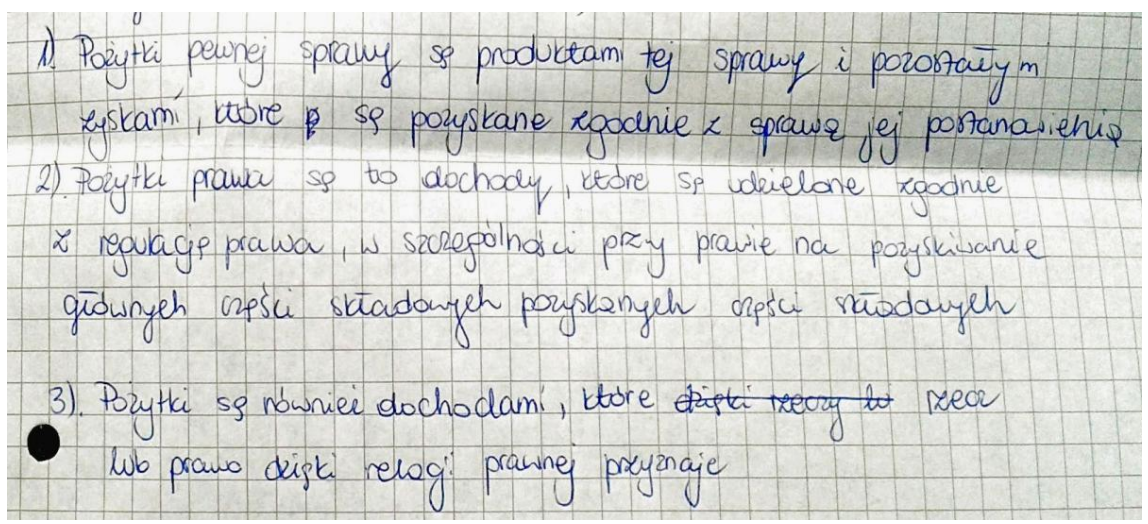

Oceniając globalnie wszystkie przekłady wykonane w pierwszej fazie eksperymentu, można stwierdzić, że przeciętna efektywność zadania (tj. ilość przełożonego tekstu) wyniosła około $60 \%$, a przeciętna jakość/poprawność przekładu - zaledwie10\%.

\subsection{Opis przekładu za pomocą tekstu paralelnego}

W tej części eksperymentu studenci otrzymali zadanie przełożenia tego samego tekstu, ale ty razem bez pomocy słowników, mając do dyspozycji jedynie polski kodeks cywilny, będący odpowiednikiem Bürgerliches Gesetzbuch. Najpierw otrzymali polecenie znalezienia odpowiedniego przepisu w polskim systemie prawnym, który dotyczyłby tej samej materii prawnej i umożliwiał im porównanie terminologii pod kątem ekwiwalencji. Na tej podstawie mieli ustalić odpowiedniki funkcjonalne $\mathrm{w}$ polskim systemie 
prawnym. Ta część zadania nie sprawiła studentom trudności, ponieważ w ramach przedmiotu Wstęp do prawoznawstwa polskiego otrzymali stosowne przygotowanie.

$\mathrm{Na}$ wykonanie zadania studenci mieli tyle samo czasu co w pierwszej fazie eksperymentu (15 minut). W tym czasie studenci ustalili przepis polskiego Kc, który stanowił podstawę porównania systemowego i sposobu utekstowienia materii prawnej. Właściwym przepisem w polskim systemie prawnym w tym wypadku jest art. 53 oraz $54 \mathrm{Kc:}$

Art. 53.

$\$ 1$. Pożytkami naturalnymi rzeczy są jej płody i inne odłączone od niej części składowe, o ile według zasad prawidłowej gospodarki stanowią normalny dochód z rzeczy.

$\$ 2$. Pożytkami cywilnymi rzeczy są dochody, które rzecz przynosi na podstawie stosunku prawnego.

Art. 54.

Pożytkami prawa są dochody, które prawo to przynosi zgodnie ze swym społeczno-gospodarczym przeznaczeniem.

Aby łatwiej było porównać przepisy, poniżej zostanie powtórnie zaprezentowany $\$ 99$ BGB.

$\$ 99$ Früchte

(1) Früchte einer Sache sind die Erzeugnisse der Sache und die sonstige Ausbeute, welche aus der Sache ihrer Bestimmung gemäß gewonnen wird.

(2) Früchte eines Rechts sind die Erträge, welche das Recht seiner Bestimmung gemäß gewährt, insbesondere bei einem Recht auf Gewinnung von Bodenbestandteilen die gewonnenen Bestandteile.

(3) Früchte sind auch die Erträge, welche eine Sache oder ein Recht vermöge eines Rechtsverhältnisses gewährt.

W porównaniu należało wydzielić te elementy zdań, które mają tę samą funkcję. W przypadku definicji legalnych można wyodrębnić nazwy występujące $\mathrm{w}$ funkcji definiendum, a w zwrocie definiującym genus proximum, czyli termin nadrzędny w stosunku do definiendum oraz konstytutywne cechy definiowanego pojęcia. 
Tabela 2. Elementy definiendum

\begin{tabular}{|l|l|}
\hline $\begin{array}{l}\text { Elementy regulacji niemieckiej - definien- } \\
\boldsymbol{d u m}\end{array}$ & Elementy regulacji polskiej - definiendum \\
\hline $\begin{array}{l}\text { Früchte einer Sache sind die Erzeugnisse } \\
\text { der Sache }\end{array}$ & pożytkami naturalnymi rzeczy są jej płody \\
\hline Früchte eines Rechts sind die Erträge & pożytkami prawa są dochody \\
\hline $\begin{array}{l}\text { Früchte sind auch die Erträge [...] eines } \\
\text { Rechtsverhältnisses }\end{array}$ & $\begin{array}{l}\text { pożytkami są także dochody, które przynosi } \\
\text { stosunek prawny (pożytki cywilne) }\end{array}$ \\
\hline
\end{tabular}

Jak widać z powyższego zestawienia, zarówno w niemieckim, jak i w polskim systemie prawnym rozróżnia się trzy rodzaje pożytków: Früchte, Früchte einer Sache, Früchte eines Rechts i odpowiednio pożytki cywilne, pożytki naturalne i pożytki prawa. Z porównania wynika, że tylko w przypadku terminu Früchte eines Rechts zachodzi zgodność w zakresie liczby składników i motywów nazwotwórczych. Inaczej jest w przypadku niemieckiego terminu Früchte einer Sache, zbudowanego z dwóch składników, którego polskim odpowiednikiem funkcjonalnym jest termin pożytki naturalne rzeczy, składający się trzech elementów leksykalnych, ponieważ w polskim systemie prawnym tego rodzaju pożytki ustawodawca dodatkowo określa jako „naturalne”. Podobnie jest $\mathrm{z}$ terminem Früchte, który w polskim systemie prawnym zawiera dodatkowy motyw nazwotwórczy. Polski ustawodawca zdefiniował bowiem pożytki pochodzące ze stosunku prawnego jako pożytki cywilne. Jeśli chodzi o zgodność pojęciową, to jej ustalenie wymaga analizy definiensa. Użycie właściwego terminu w funkcji genus proximum zależy od rodzaju pożytków. Wymagana jest tu zatem znajomości cech konstytutywnych tych prawnie zdefiniowanych pojęć. W każdym bowiem przypadku pożytki definiowane są jako rodzaj dochodu. Rozgraniczenie pochodzenia dochodu będzie stanowić podstawę do rozróżnienia tych pojęć w funkcji genus proximum.

Tabela 3. Elementy genus proximum

\begin{tabular}{|l|l|}
\hline $\begin{array}{l}\text { Elementy regulacji niemieckiej - genus } \\
\text { proximum }\end{array}$ & $\begin{array}{l}\text { Elementy regulacji polskiej - genus proxi- } \\
\text { mum }\end{array}$ \\
\hline $\begin{array}{l}\text { Früchte einer Sache sind die Erzeugnisse } \\
\text { der Sache und die sonstige Ausbeute }\end{array}$ & $\begin{array}{l}\text { pożytkami naturalnymi rzeczy są jej płody } \\
\text { i inne zyski (uzyski) }\end{array}$ \\
\hline Früchte sind auch die Erträge & pożytkami są także dochody \\
\hline
\end{tabular}

* Użycie nazwy uzyski jest semantycznie bliższe niemieckiemu wyrazowi Ausbeute, ale nie spełnia ona norm preskryptywnych w polskim systemie prawnym. 
Jak wynika z zestawienia, dochodem w przypadku instytucji Früchte einer Sache są Erzeugnisse, czyli płody, jakie wydaje rzecz, stąd polski ustawodawca precyzyjniej określa je jako pożytki naturalne. W niemieckiej regulacji natomiast dodatkowo występuje określenie und andere Ausbeute, które nie ma odpowiednika funkcjonalnego w systemie polskim, dlatego że jest on inkludowany przez termin pożytki naturalne. Fakt ten nie uprawnia zatem tłumacza do zastosowania przekładu dosłownego, bo przekład tego wyrażenia powinien nastąpić w kontekście problematyki dochodu, o którym mowa. Przekład nazwy Ausbeute na np. urobek odnosiłby się bowiem do kopalin, a przecież nie tylko kopaliny są pożytkami naturalnymi. Podobnie plon odnosi się do produkcji rolnej, ale już nie do przemysłu wydobywczego. Zasadne jest zatem tłumaczenie nazwy Ausbeute na tyle szeroko, by obejmowała ona wszelkie pożytki naturalne, stąd najbardziej ekwiwalentną i uzasadnioną kontekstem przepisu będzie polska nazwa $z y s k$. Nieco bardziej złożona jest sprawa instytucji Früchte i Früchte eines Rechts, ponieważ oba terminy zawierają to samo genus proximum, oznaczające dochód. Kluczową sprawą jest tu pochodzenie dochodu, o czym informuje definiens. Istotne cechy pojęcia, które wskazują na pochodzenie dochodu, zostaną zestawione poniżej.

Tabela 4. Differentia specifica w regulacji niemieckiej i polskiej

\begin{tabular}{|l|l|}
\hline $\begin{array}{l}\text { Elementy regulacji niemieckiej - differen- } \\
\text { tia specifica }\end{array}$ & $\begin{array}{l}\text { Elementy regulacji polskiej - differentia } \\
\text { specifica }\end{array}$ \\
\hline $\begin{array}{l}\text { welche aus der Sache ihrer Bestimmung ge- } \\
\text { mäß gewonnen wird }\end{array}$ & $\begin{array}{l}\text { które [prawo to] przynosi zgodnie ze swym } \\
\text { [społeczno-gospodarczym] przeznacze- } \\
\text { niem }\end{array}$ \\
\hline $\begin{array}{l}\text { welche das Recht seiner Bestimmung ge- } \\
\text { mäß gewährt }\end{array}$ & $\begin{array}{l}\text { które prawo to przynosi zgodnie ze swym } \\
\text { [społeczno-gospodarczym] przeznacze- } \\
\text { niem }\end{array}$ \\
\hline $\begin{array}{l}\text { insbesondere bei einem Recht auf Gewin- } \\
\text { nung von Bodenbestandteilen die gewonne- } \\
\text { nen Bestandteile }\end{array}$ & $\begin{array}{l}\text { inne odłączone od niej (rzeczy) części skła- } \\
\text { dowe }\end{array}$ \\
\hline $\begin{array}{l}\text { welche eine Sache oder ein Recht vermöge } \\
\text { eines Rechtsverhältnisses gewährt }\end{array}$ & $\begin{array}{l}\text { które rzecz przynosi na podstawie stosun- } \\
\text { ku prawnego }\end{array}$ \\
\hline
\end{tabular}

Z porównania elementów tworzących differentia specifica niemieckich i polskich unormowań wyraźnie widać, że choć pod względem językowym (składniowym) istnieją różnice, to porównywane unormowania ze względu na funkcję i cel przepisów o pożytkach są podobne i należy je uznać za w peł- 
ni ekwiwalentne. Podobne stanowisko w sprawie ustalania odpowiedników prawnych w translatach zajmuje Sandrini (1996: 156):

Die Suche nach dem funktionalen Gegenüber in der zielsprachlichen Rechtsordnung erfolgt über die Einordnung des Begriffes in einem größeren Zusammenhang. Jeder Begriff ist vor allem einmal als Element einer Regelung bzw. einer Norm zu sehen. Diese rechtliche Mikrostruktur wird wiederum innerhalb eines nationalen Rechtssystems in einem größeren Zusammenhang gebracht und zu einem Teilgebiet des Rechtssystems [...] zusammengefaßt. Eine solche Zuordnung über eine zugegebenermaßen grobe Klassifikation kann nur im Zusammenhang mit einem Definitionsvergleich erfolgen.

\subsection{Wynik badania właściwego}

\section{Efektywność}

Z analizy wszystkich prac wynika, że około 80\% studentów wykonało zadanie w całości w zaplanowanym czasie. Pozostali byli bliscy ukończenia przekładu.

\section{Jakość}

Na podstawie przeprowadzonej analizy prac pod kątem jakości przekładu należy stwierdzić, że studenci wykonali zadanie dobrze lub nawet całkiem poprawnie. W zdecydowanej większości prac stosowano prawidłowe ekwiwalencje. Jedynym problemem translacyjnym we wszystkich pracach okazał się przekład nazwy złożonej sonstige Ausbeute, która w polskim systemie prawnym nie ma bezpośredniego odpowiednika terminologicznego ${ }^{7}$. Fakt ten należy tłumaczyć tym, że studenci pierwszego roku nie mieli jeszcze odpowiedniego przygotowania metodologicznego pod kątem przekładu terminów/ nazw bezekwiwalentnych. Oceniając jakość przekładu w drugiej fazie eksperymentu, należy uznać, że kryteria poprawności terminologicznej i językowej zostały spełnione w $80 \%$. Bardzo wyraźnie poprawiła się komunikatywność przekładu, co wynika z lepszego zrozumienia tłumaczonego tekstu po porównaniu z polskimi przepisami. Wykorzystanie tekstu paralelnego wpłynęło również korzystnie na styl i poprawność składniową translatu. Dla potwierdzenia naszych wniosków podajemy oba przekłady niemieckiego przepisu na język polski wykonane przez tę samą osobę.

7 Według Dudena (online) Ausbeute oznacza Ertrag, Gewinn aus einer bestimmten Arbeit. Natomiast słownik Pons (online) podaje dla tej nazwy następujące odpowiedniki w języku polskim: eksploatacja, plon, produkcja, urobek, uzysk, wydajność, zysk. 


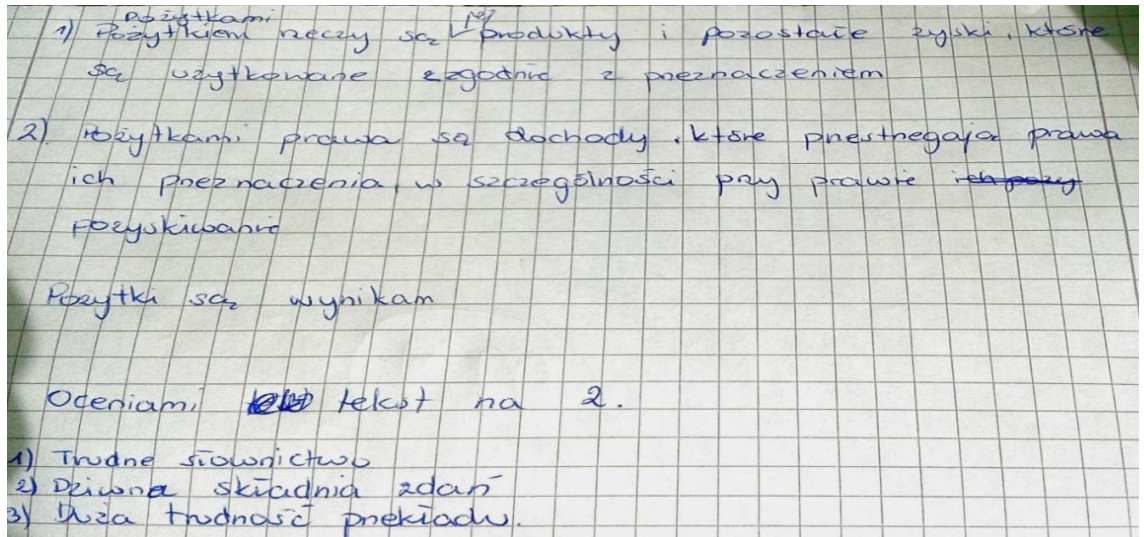

Skan 2. Efekt przekładu za pomocą słownika

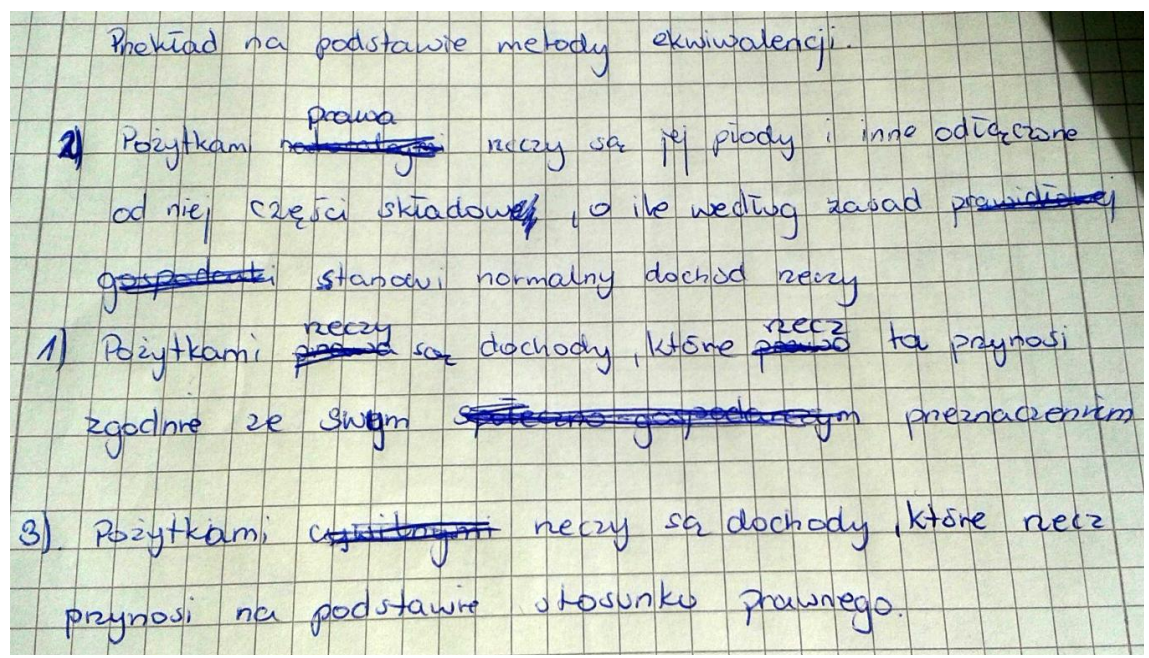

Skan 3. Efekt przekładu za pomocą tekstu paralelnego

\section{Wnioski}

Zastosowanie metody przekładu $\mathrm{z}$ wykorzystaniem paralelnych tekstów prawnych pozwoliło bardzo wyraźnie poprawić wszystkie parametry pracy tłumacza. 
1. Czas przeznaczony do wykonania zadania translacyjnego został wykorzystany efektywnie, ponieważ $\mathrm{w}$ tym samym czasie przetłumaczono więcej tekstu.

2. Merytoryczna poprawność przekładu wzrosła przeciętnie o $70 \%$.

3. We wszystkich translatach wyraźnie poprawiły się styl i składnia.

Aby ta metoda mogła być skutecznie stosowana, niezbędne są:

1) szersza wiedza o wyjściowym i docelowym systemie prawnym, a zwłaszcza o najbardziej powszechnych instytucjach prawa i stosunkach prawnych;

2) wykształcenie umiejętności ustalania przepisów regulujących podobną materię w wyjściowym i docelowym systemie prawnym;

3) umiejętność identyfikacji nazw jako terminów;

4) umiejętność identyfikacji cech pojęciowych terminów w celu ustalenia stopnia ich ekwiwalencji na podstawie stosownych regulacji prawnych,

5) umiejętność porównanie systemów prawnych w niezbędnym do tego zakresie w celu znalezienia funkcjonalnych odpowiedników.

\section{Literatura}

Berdychowska, Z., 1999, „Fachsprachliche Kollokationen und terminologische Ausdrücke in der Sprache der Rechtswissenschaft", [w:] Vielfalt der Sprache. Festschrift für Aleksander Schulc zum 70. Geburtstag, M. Kłańska, P. Wiesinger (red.), Wien, s. 259-274.

Bocquet, C., 1994, Pour une méthode de traduction juridique, Prilly.

Darski, J., 2012, Gramatyka niemiecka z uwagami konfrontatywnymi, Poznań. Groot de, G.-R., 1990, „Die relative Äquivalenz juristischer Begriffe und deren Folge für mehrsprachige juristische Wörterbücher", [w:] Translation and Meaning, part 1, M. Thelen, B. Lewandowska-Tomaszczyk (red.), Maastricht, s. 122-128.

Groot de, G.-R., 2002, „Rechtsvergleichung als Kerntätigkeit bei der Übersetzung juristischer Terminologie", [w:] Sprache und Recht, U. Haß-Zumker (red.), Berlin - New York, s. 222-239.

Helbig, G., Buscha, J., 1984, „Deutsche Grammatik. Ein Handbuch für den Ausläderunterricht", Leipzig.

Iluk, J., 2012, „Terminologia prawna i prawnicza z perspektywy interlingwalnej", [w:] Studia Linguistica, t. 31, s. 7-21. 
Iluk, Ł., 2015, „Metoda poszukiwania i ustalania terminów w różnych systemach prawnych w oparciu o akty normatywne", [w:] Studia Niemcoznawcze, t. 55, Warszawa, s. 633-646.

Kielar, B., 2007, „Wiedza specjalistyczna tłumacza - na przykładzie tekstów prawnych", [w:] Języki Specjalistyczne 7. Teksty specjalistyczne jako nośniki wiedzy fachowej, Warszawa, s. 19-33.

Kielar, B., 2010, „Drogi i bezdroża tłumaczenia tekstów prawnych”, [w:] Publikacja jubileuszowa III. Lingwistyka stosowana - języki specjalistyczne - dyskurs zawodowy, Warszawa, s. 131-147.

Kielar, B., 2013, Zarys translatoryki, Warszawa.

Kilian, A., 1996, Słownik języka prawniczego i ekonomicznego niemiecko-polski, t. 2, Warszawa.

Kilian, A., 2000, Słownik języka prawniczego i ekonomicznego, polsko-niemiec$k i$, t. 1, Warszawa.

Kilian, A., 2009, Słownik języka prawniczego i ekonomicznego niemiecko-polski, t. 1, Warszawa.

Kienzler, I., 2007, Słownik terminologii gospodarczej. Bankowość. Finanse. Prawo. Niemiecko-polski, polsko-niemiecki, wyd. 2, Warszawa.

Kierzkowska, D., (red.), 2005, Kodeks tłumacza przysięgłego z komentarzem, Warszawa.

Kozieja-Dachterska, A., 2006, Großwörterbuch der Wirtschafts- und Rechtssprache. Deutsch-polnisch, t. 1, Warszawa.

Krzysztoforska-Weisswasser, Z., 1995, „Wykorzystanie tekstów paralelnych przy tłumaczeniu wyroków w procesie cywilnym, [w:] Lingua legis, nr 2, s. 18-26.

Kubacki, A., 2013, „Teksty paralelne jako narzędzie pomocnicze przy sporządzaniu tłumaczeń (specjalistycznych)", [w:] Comparative Legilinguistics, Vol. 13, s. 145-157.

Langenscheidts Großwörterbuch, Deutsch als Fremdsprache, 1997, Berlin-München.

Lukszyn, J., Zmarzer, W., 2001, Teoretyczne podstawy terminologii, Warszawa. Małgorzewicz, A., 2012, Die Kompetenzen des Translators aus kognitiver und translationsdidaktischer Sicht, Wrocław.

Małgorzewicz, A., 2013, „Socjokognitywna kompetencja tłumacza w procesie translacji”, [w:] Lingwistyka Stosowana, nr 8, s. 81-91.

Matulewska, A., 2005, „Własność i zobowiązania w aspekcie translatorycznym polsko angielskim i angielsko-polskim", [w:] Investigationes Linguisticae, vol. 12, Poznań, s. 62-76.

Pawęska, M., 2008, Lexikon der juristischen Fachbegriffe, Warszawa. 
Pieńkos, J., 2003, Podstawy przekładoznawstwa. Od teorii do praktyki, Zakamycze.

Pommer, S., 2006, Rechtsübersetzung und Rechtsvergleichung. Translatorische Fragen zur Interdisziplinarität, Frankfurt/M.

Sandrini, P., 1996, Terminologiearbeit im Recht / Deskriptiver begriffsorientierter Ansatz vom Standpunkt des Übersetzers, Wien.

Wüster, E., 1979, Einführung in die allgemeine Terminologielehre und terminologische Lexikographie, Wien - New York.

Schmidt-König, Ch., 2005, Die Problematik der Übersetzung juristischer Terminologie, Eine systematische Darstellung am Beispiel der deutschen und französischen Rechtssprache, Münster.

Stolze, R. 1999, „Expertenwissen des juristischen Fachübersetzers”, [w:] Übersetzen von Rechtstexten - Fachkommunikation im Spannungsfeld zwischen Rechtsordnung und Sprache, P. Sandrini (red.), Tübingen, s. 45-62.

Zieliński, L., 2005, „Kulturologiczna determinacja wyboru ekwiwalentu przez tłumacza tekstów prawnych z zakresu zobowiązań umownych", [w:] Języki Specjalistyczne, nr 5: Teksty specjalistyczne w kontekstach zawodowych i ttumaczeniach, Warszawa, s. 38-47.

\section{The influence of translation approach on the effectiveness and correctness of legal text translation as part of translation exercises}

\section{Summary}

The following paper describes a translation experiment carried out to convince students of low effectiveness of translating with dictionaries and without adequate knowledge to describe the law-related issues. It involves translating a German legal regulation into Polish in two stages; in the first stage the students were allowed to use dictionaries, whereas in the subsequent one they translated the text using bilingual parallel texts. This text was intendned to serve as a model description of a similar content at the level of terminology, grammar and stylistics. In the second stage of the experiment, the students were encouraged to use more effective translation strategies, where legal knowledge is of great importance, and especially the ability to establish legal regulations referring to similar legal issues in the source and target legal system. It may be therefore concluded that by changing translation techniques it is possible to correct all the parameters of translation without the need of further practice.

Keywords: functional equivalence, translation based on parallel texts, translation of legal texts 